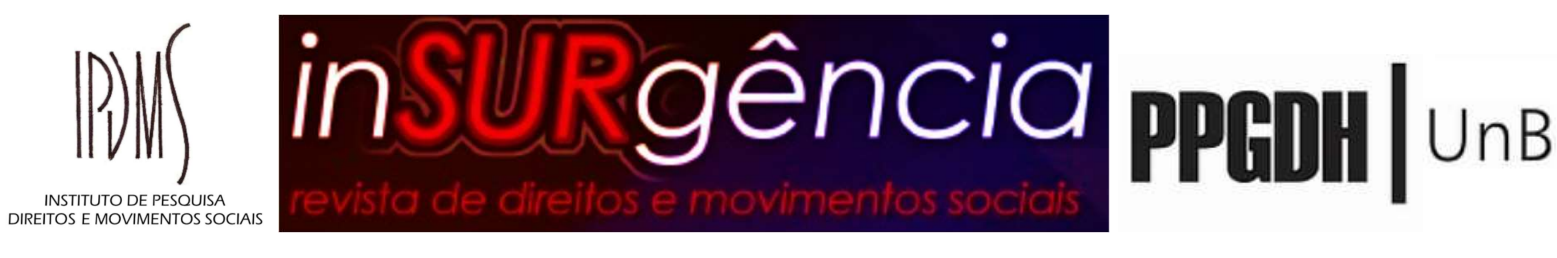

\title{
DE ONDE VEM A LUTA?
}

para a Turma Nilce de Souza Magalhães

Ricardo Prestes Pazello ${ }^{1}$

De onde vêm tantos e tantas

Sementes de nossas lutas,

Rebentos que a vida implanta,

Sedentos de fala e escuta?

Nascem da vida do povo

E de sua dura batalha,

São a promessa, o renovo

Do mundo que agora orvalha.

Filhos das revoluções

Mais atrevidas, mais belas,

Do México ouvem-se os sons

Que ecoa na Venezuela.

Lembrando-se que Gonaives

Agrupa-se logo aqui

A uma Petite Rivière

Com Dave Kelsens do Haiti.

Por Guaraí é que adentra

$\mathrm{O}$ veio rural proletário,

No Norte ninguém se isenta

Da herança de Olga Benário.

\footnotetext{
${ }^{1}$ Professor do Curso de Direito e do Programa de Pós-Graduação em Direito da Universidade Federal do Paraná (UFPR). Doutor em Direito das Relações Sociais pelo Programa de Pós-Graduação em Direito da Universidade Federal do Paraná (PPGD/UFPR). Mestre em Filosofia e Teoria do Direito pelo Curso de Pós-Graduação em Direito da Universidade Federal de Santa Catarina (CPGD/UFSC). Bacharel em Direito pela UFPR.
} 
Legado que é de amplidão

Pois apresenta Palmares

Como fosse a Nova União

De florestas, campos, mares.

Campo Verde que, inclusive,

Serve sempre de ofertório;

Eis a bênção que revive

Orações de Dom Osório.

Também um beato será

Patrono forte e certeiro:

Sobe a Serra em Tangará

Novo Antônio Conselheiro.

A revolta desagrava

O sumiço de Porfírio

E, agora, em Cana-Brava

Minaçu tem novo filho.

Novos filhos no carreto

Vera e Sophia dão suas mãos,

Vêm de Pereira Barreto

Outros bravos Três Irmãos.

E se juntam em tempos graves,

Que a ninguém pode enganar,

Filhos de Denis Gonçalves

Assentado em Goianá.

Não se engana e não se esbarra 
De onde vem toda essa gente,

Desde Conceição da Barra

Paulo Vinhas'stá presente.

E em Água Doce do Norte

Deságua também e espoca

Fidelidade que corte

O Córrego da Pipoca.

Banhando-se Iaras mais cedo,

Mais tarde chega-se a Apiaí

Do Professor Luís Macedo

Aliado ao firme Zumbi.

No Quilombo Porto Velho

Esta história corre e sangra

E com ela me avermelho

Pelas bandas de Iporanga.

De Itaberá, na agrovila,

Vem luta de agricultor,

Assim como em Piratinga

Se relembra Laudeonor.

Oito de outubro foi a data

Da vitória em Simão Dias,

Eis o que a história retrata

Por virtude e valentia.

Bem assim nasceu Heitor,

Um guerreiro de Orocó,

Batizado no esplendor 
Do Velho Chico, o melhor.

É o Campo Grande que dança

Junto a Ronaldo Valença,

Obtendo Nova Esperança

Que em Mossoró nasce intensa.

O gosto do Jenipapo

Reforça quem cumpre a sina

De enfrentar o vil sopapo

Que enraivece Correntina.

De Canudos, rebelados

Subiram o Monte Santo

Que, no Povoado Salgado,

Reencarnaram com encanto.

Dizem que até prefeito vinga

Pelo que se comunique,

No jornal de Itapetinga

Vai denúncia em Maiquenique.

Os tambores maranhenses

Ressoam em Curitiba,

Alcântara tem forense

Luta em Itamatatiua.

Seja em Maracaçumé

Piriá ou Bacabal,

Um Diamante Igarapé

$\mathrm{Na}$ Santa Cruz é um sinal 
De que mesmo em Açailândia

Não existe terra morna

Pois ali o que se expande é a

Ocupação em Califórnia.

Chegam mais algumas filhas

Como em Lagoa Grande temos.

Esperamos que com Lívia

Cresça a Agrovila Kênio.

Assim como vem ditosa

De Itapecuru-Mirim

Em Morros, Conceição Rosa,

O que importa é ter Jasmim.

Cruzando esse Brasil moço

À Roça Nova se chega

E trazendo Tino Afonso

Em Vacaria é Nova Estrela

Que genuína vem a cargo

Dos que não vão estar imunes,

Casamento em Abelardo,

Força de Roseli Nunes.

Em Laranjeiras do Sul

Herda o Primeiro de Maio

Rio Bonito do Iguaçu

De Ireno Alves o trabalho.

Em Rio Branco do Ivaí

Retorna Egídio Brunetto, 
Memória que em Tibagi

Alegra o Rancho um momento.

Fundo Paiol de Telha,

Séculos em Guarapuava

Conversando com Teixeira

Soares, viva Che Guevara!

E não é que tem Zapata

Que por Ponta Grossa habita?

Assim como vem da Lapa

Luta feita na Restinga!

Chico Mendes em Ibema

Navegando em Cascavel,

Reassentado tem por lema,

Território por troféu.

Ramilândia é resistência

No dia Dezesseis de Maio;

Já o Tigre na Querência

Aponta contra os lacaios.

E assim se sabe da luta,

Se sabe de onde ela vem.

Pois vem do povo que estuda,

Que se organiza também.

Curitiba, 17 de dezembro de 2019. 